\title{
Church and state in South Africa and human rights
}

\author{
Author: \\ Piet J. Strauss ${ }^{1}$

\section{Affiliation:} \\ ${ }^{1}$ Department of Church \\ History and Church Polity, \\ University of the Free State, \\ South Africa

\section{Correspondence to:} \\ Piet Strauss \\ Email: \\ straussp@ufs.ac.za \\ Postal address: \\ PO Box 339, Bloemfontein \\ 9300 , South Africa \\ Dates: \\ Received: 25 May 2015 \\ Accepted: 06 Aug. 2015 \\ Published: 02 Oct. 2015 \\ How to cite this article: \\ Strauss, P.J., 2015, 'Church \\ and state in South Africa and \\ human rights', In die Skriflig \\ 49(1), Art. \#1990, 6 pages. \\ http://dx.doi.org/10.4102/ \\ ids.v49i1.1990

\section{Copyright:} \\ (c) 2015. The Authors. \\ Licensee: AOSIS \\ OpenJournals. This work is \\ licensed under the Creative \\ Commons Attribution \\ License.
}

\section{Read online:}

After the Second World War, there was a universal rise and greater acknowledgement of human rights, which entered churches and ecumenical organisations' way of thinking. Human rights influenced the church's understanding of justice and human dignity both internally and externally. The concept of human dignity came from the biblical believe that man is created in the image of God. In South Africa human rights were also increasingly recognised and respected. A charter of human rights was included as chapter 2 of the 1996 Constitution and churches regard human dignity as a central tenet of their approach to members and nonmembers. Differences between church and state on the issue have arisen as the result of differences on the freedom of religion. Church and state in South Africa can complement each other in the promotion of human dignity.

Opsomming: Kerk en staat in Suid-Afrika en menseregte. Na die Tweede Wêreldoorlog is menseregte wêreldwyd erken en aanvaar. Dit was ook die geval in kerke en ekumeniese organisasies. Menseregte het kerke se siening van geregtigheid en menswaardigheid in hulle interne sowel as eksterne optrede beïnvloed. Die begrip menswaardigheid het ontstaan uit die bybelse oortuiging dat die mens na die beeld van God geskape is. In Suid-Afrika is menseregte ook toenemend erken en aanvaar. 'n Verklaring van menseregte is as hoofstuk 2 in die 1996-grondwet ingesluit en kerke beskou menswaardigheid as toonaangewend in hulle benadering van mense binne en buite die kerk. Verskille tussen die kerk en die staat in Suid-Afrika oor menseregte het ontstaan as gevolg van verskille oor die inhoud van die vryheid van godsdiens. Teen hierdie agtergrond kan kerk en staat mekaar egter aanvul in die bevordering van menseregte.

\section{Introduction}

There is a tradition in reformed theological circles that human rights are humanistic and not Christian in origin, stemming from the Aufklärung of the 17th century (Jonker 1984:47-48). ${ }^{1}$ It holds that the church can do without the effect of human rights in its actions if it is guided by the Word and Spirit of God. The argument is often used that a biblically orientated church order has no need for anything outside its ecclesiological tradition or way of thinking if it is based on Scripture. ${ }^{2}$

Opposing this tendency is the view that has developed in some reformed church political circles since the Second World War and the Universal Declaration of Human Rights of the United Nations in 1948, namely that the church must seriously take note of and accommodate the rise of human rights in the Western World. This development has a strong effect on people's, and therefore church members', view of justice - also for and in the church (Coertzen 1998:5). International ecumenical organisations like the World Council of Churches, the Lutheran World Federation and the World Alliance of Reformed Churches (since 2010 the World Communion of Reformed Churches) became advocates for the universal acceptance of human rights. Even in the Roman Catholic Church the Council of Vaticanum II (in the early 1960s) paid serious attention to the concept of human rights (Jonker 1984:50; Koffeman 2009:326-327).

Members of churches therefore expect from church assemblies, commissions and tribunals to act justly in matters involving them. This expected justice is not necessarily stipulated or even touched on in the specific church order, but correlates with members' general feeling of what justice is. This is a feeling which is influenced by the general idea or concept of human rights (Strauss 2007:202-203).

Moltmann (1984:19) puts it that human rights entered the process of constitution making in Europe and North America 'at the time of the Enlightment ... not independent of Christian influence ... and so attained a worldwide political significance'.

2.Cf. the difference in the church orders of the Reformed Churches in South Africa (RCCO; Visser 1999) and the Dutch Reformed Church (NGK 2011b) in reflecting cognisance of the recent declaration of human rights in the South African constitution (1996). Strauss
(2013:129-136) gives more detail. 
It is important to note that the content of human rights as accepted in different parts of the world and in different societies often differ in detail, but that the general concept or idea is widely accepted. This is also true of many churches. For example: Reformed theologians may differ on the detail of it, but many are of the opinion that human rights centre around human dignity. A dignity which can be filled with biblical truths and which, in itself, can be accepted as a universal truth.

For Koffeman human dignity should be based on the biblical idea of creation and man being created in the image of God. In 1988 in Harare, the General Assembly of the World Council of Churches declared that Christians believe that God created all men and women with dignity and rights. On the basis of this there is equality between all men and women, youth and elderly people, nations and cultural groups. The same idea was accepted by Vaticanum II (Koffeman 2009:329-330).

Earlier Jonker (1984:47ff.), following Velema in this regard, made a worthy attempt to differentiate between a biblically founded and biblically unfounded idea of human rights. For Jonker a biblical understanding of human rights takes as its point of departure the dignity of all human beings as being created in the image of God. According to him the correct understanding of human rights can only follow on the acceptance that God created mankind in his image. God placed mankind on earth with the calling to reign and develop it according to his will. In this, mankind is God's representative. God created a new relationship with people after they had disobeyed him and fallen into sin. He dwells in them through his Spirit and restores his image in them for them to fulfil the calling he gave them as their Creator. All these truths indicate that God created mankind with a dignity and worth, which had to be recreated or restored after the Fall. This dignity includes the possibility to live up to the call he gave them as his representatives on earth. In relation to other people it becomes the right to answer this call. Naturally this should be done with the required responsibility (Jonker 1984:52; see the same line of thought in Moltmann 1984:21).

According to Jonker (1984:47ff.) God, in his grace, gave mankind certain opportunities. A list of these opportunities can be based on the Ten Commandments. The list includes: the opportunity to live; the freedom and time to serve him; to obey those who have authority in aspects of life over them; to love, respect and protect other human beings; to enter into marriage as a permanent bond with a will to love and stay truthful; to possess property and to have it acknowledged and protected as one's own; to receive and know the truth in general; and to receive justice. In relation to God these opportunities are given by God out of grace, but, in relation to other people in human society, it becomes rights. Examples of these rights that emanate from these opportunities are: the right to live; the freedom to serve God; the right to obey certain authorities; the right to love, respect and protect fellow human beings - generally within the law; the right to possess property; and to hear the truth.
Jonker (1984:54-55) supports his argument with this example: If I receive a gift from my parents for my birthday, it is a gift given by them. However, after receiving it I have got the right of an owner on it and the right to use it for my own purposes. I can use it in any way I like as long as I remain within certain norms of conduct and the law.

The acceptance of the idea of human rights without necessarily accepting a certain version of it was stimulated by the climate created by the above-mentioned and other declarations of human rights (like the well-known European Declaration of Human Rights), and efforts of churches and ecumenical organisations to promote these rights. In South Africa a charter of human rights became chapter 2 of the 1996 Constitution. Like the European declaration of human rights, this charter is meant to be the highest law in South Africa (Torfs 2003:271). It is seen as the 'cornerstone of democracy in South Africa' (Rautenbach \& Malherbe 1998:8; see the same words in article 7.1 of the South African Constitution as the first article of the declaration of human rights; Constitutional Assembly 1997:5). It also aims at promoting human dignity, equality and freedom in the South African society governed by the state authorities (Kleyn \& Viljoen 1998:267).

Against this background, Koffeman (2009:328) indicates that the formulation of specific human rights is still developing and has not yet come to an end. It normally emanates from a central idea, but its formulation is linked to a specific cultural and social context. This central idea is applicable in every state. From there it has a stronger and weaker influence on other spheres of societies other than the state. An influence, which lets itself be experienced in non-state situations where some kind of justice is needed. The church can also use specific human rights on a firm theological and church orientated basis. Koffeman (2009) adds:

Een beschouwing over mensenrechten roept niet alleen de vraag op welke rol de mensenrechten spelen in de mondiale politiek, maar ook die welke rol mensenrechten spelen binnen de kerk. Men kan immers zeggen: 'Geen vrijheid van godsdienst zonder vrijheid in de godsdienst'. Soms lijkt het er echter op dat kerken het veel eenvoudiger vinden overheden aan te spreken op hun plicht de mensenrechten veilig te stellen dan dat zij zelf in hun interne leven de mensenrechten daadwerkelijk ook een plek geven. Mensenrechten lijken dan vanuit het perspectief van de kerken 'alleen geschikt voor uitwendig gebruik. (p. 330)

According to Koffeman (2009:329) the acceptance of freedom of religion by the church, leaves the latter with two unavoidable responsibilities: to promote a package of human rights of which freedom of religion is part of, and to promote freedom in religion. Freedom in religion recognises the biblical fact that faith is an inner, spiritual conviction and should be treated as such. It should not be forced or made compulsory. The only force in this regard should come from the Word and the Spirit of God.

Human rights, in biblically orientated terms, force the church to incorporate it as a means of justice for and in the church (Coertzen 1998:5) - a means of justice as something without 
which the church, in fulfilling its task in modern times, cannot do. The organised church, as an institution in society, uses all aspects of creation or human life to serve the Christian faith. Any church, as viewed by the Bible, exists mainly because of its calling to promote the Christian faith, that is, to plant and build the Christian faith amongst its members and outsiders. In this process, for instance, it uses the art of building to erect churches with symbolic lines indicating truths of the Bible, money to translate and carry the message of Scripture, understandable language to preach and the rules of natural justice in disciplinary actions (Strauss 2010:2). A church driven by the Christian faith should have the desire to do the things of faith with justice or in a just and fair way. A specific church should accept certain human rights in such a way that it suits that specific church in its circumstances as, in principle, an institution of faith.

The church should thus use human rights under the umbrella of the general idea of it as the rights referred to earlier, namely rights based on human dignity. A biblical implementation of human rights with an aim to protect an acceptable human dignity implies that the church remains true to its head, Jesus Christ and his authority.

All this makes the topic 'Church and state in South Africa and human rights' a very relevant one. In this article the situation in South Africa concerning this topic - be it along philosophical or ecclesiastical lines - as a potential problem, is investigated and evaluated. The problem may develop from a difference between church and state on the basic approach of human rights and the implementation of it.

\section{The state and the South African charter of human rights}

The new political dispensation or state in South Africa, which came into being in 1994, brought a new democratic constitution in 1996. It is a constitution strongly based on individual human rights with a clear 'no' to the negative past of apartheid South Africa. The title of an official book on the new constitution The Constitution of the Republic of South Africa - one law for one nation (Constitutional Assembly 1997) illustrates this. The title makes it clear that it opposes the overall idea of apartheid, namely that of different nations 'connected' to their own national states.

Chapter 2 of the Constitution or articles 7-39 consists of a so-called Bill of Rights, which is nothing less than a South African charter of human rights with constitutional power (Constitutional Assembly 1997:5-17).

As mentioned, article 7 calls the Bill of Rights 'a cornerstone of democracy in South Africa.' A cornerstone aimed at the human dignity, equality and freedom of all the individual citizens of the republic, for the Bill of Rights, as a definition of the South African state, consists of millions of individuals who together - as individuals - form the South African nation. The Bill of Rights aims at the rights of these individuals.
Dlamini (1995:123) describes the Constitution as revolutionary and new. The earlier supremacy of parliament in apartheid South Africa is replaced by that of the Constitution in the new democratic South Africa. A core of this Constitution is the power of the Constitutional Court to revise proposed laws in parliament, the judgements of the courts and to have the final word on matters in society with constitutional implications (cf. Constitutional Assembly 1997:7). The aim is to transform the whole South African judicial system to be in line with the basics of the Bill of Rights.

This means that the Constitutional Court has to lead the South African society through its interpretation and implementation of the Constitution. Members of Parliament no longer have the power of final judgement: this power has been transferred to the judiciary and, finally, the Constitutional Court who should work in a climate created by a constitution aimed at equality, freedom and human dignity.

In my opinion, there is, broadly speaking, no clash between the South African government of the day and most of the Christian churches in the country over the central idea of human rights. Churches often use human rights - if not by name then by effect - in arguments about issues made public. I think it is fair to say that the central idea behind human rights goes unopposed in most churches.

This is not the reason for problems between church and state concerning human rights in South Africa. Clashes of this nature between church and state, and between certain churches only occur when specific rights or certain formulations in the Bill of Rights become a bone of contention. There may also be a clash in the ways in which the Bill of Rights is interpreted and implemented.

A problem arises, for example, when it is argued that the Bill of Rights should not only be accepted by the state and the government, but also by non-state institutions like the churchnot only in their relation to other institutions of society and other issues, but also for internal use. This can mean that the Bill of Rights is used to bind churches in their freedom to handle their own internal affairs. Taken on the formulation of it, this approach uses the Bill of Rights to limit the right to freedom of religion, belief and association of churches (articles 15 and 18 of SA Constitution, Constitutional Assembly 1997:7). Recent examples in South Africa illustrate the point.

In 2009 there was the case of the DRC (Dutch Reformed Church) congregation of Morelettapark. This consistory was taken to the South African Equality Court, because it fired a homosexual musician named J.D. Strydom. The court judged against the church. It ruled that, although Strydom's homosexual behaviour was unacceptable to the church, the consistory's action was 'unfair discrimination' in light of article 9 of the Constitution (Constitutional Assembly 1997:5, 6), because his position had nothing to do with the 'spiritual calling' of the church. He is an independent 'contractor' and not a member of the DRC. The court respected the right of 
the church to expect a certain behaviour of its members, but decided that this was not at stake (discussion in Van der Vyver 2011:1-17). Thus, this court decided on behalf of this church or congregation when people in its service should become an internal problem. It communicated respect for the church to handle its own affairs as a non-state institution, but limited its ability to do so by determining what these affairs should be. By doing so, it bordered on limiting the freedom of religion and therefore the belief of the church (Strauss 2010:3).

Freedom of religion or of the association of Christian believers with one another was disregarded by critics of a meeting of thousands of Christians on the Newlands Stadium. It was argued by politicians that this meeting, to which only believers were invited, contravened article 9 of the Constitution. They forgot the rights of freedom of religion, belief and association in articles 15 and 18, and used article 9, which is normative for the South African state as neutral in religion, also as normative for a meeting of Christian believers. They never thought of it that non-state institutions should be allowed to determine their own internal conduct or association as long as it forms no thread for the state to implement the Bill of Rights in matters or institutions under state control (Strauss 2010:3).

From an overall perspective the South African Bill of Rights opts for the freedom of religion and freedom in religion. If formulated along these lines, it becomes acceptable to a selfdetermining Christian church also. However, if the South African state or state organs such as the courts decide for the church what its beliefs or the conduct of its members should be, it negate other articles of the Bill of Rights and use article 9 as a tool to become a totalitarian state.

What is more, article 9(3) states that the state may not 'unfairly' discriminate 'directly or indirectly against anyone' on grounds like 'sexual orientation ... religion ... belief', et cetera. In itself it therefore limits or gives the implementation of article 9(3) explicitly to the state. At the same time it utters no limitation to the freedom of other spheres of society to maintain and carry its own view on the same issues. It does not oppose or limit the freedom of belief, religion and association expressed in other articles (Constitutional Assembly 1997:5).

I am convinced that articles 15 and 16 of the Bill of Rights, which also makes room, apart from other freedoms, for the freedom of opinion, allow me to criticise the finding of this court. I also feel that many supporters of the 1996 Constitution will support my interpretation of the Bill of Rights in this regard (Devenish 1995:56-57, 61). This interpretation is also acceptable in Western countries with a strong tradition of human rights.

Still under the umbrella of equality, freedom and human dignity, the above mentioned interpretation of the Bill of Rights would pass the test. The Constitution attempts to balance and reconcile the different rights of different citizens. In any case, a declared religiously neutral state will contradict itself if it tried to prescribe ethics to churches.
Whilst South African churches may accept the brunt of the South African Bill of Rights, it may differ on certain formulations or certain formulated rights. In this, article 9 is a good example. This article also prohibits so-called unfair discrimination against people on the ground of their sexual orientation (Constitutional Assembly 1997:5). To forbid homosexuality, as some churches do, is probably forbidden by article 9 .

With their acceptance of the central idea of human rights, without accepting every individual right or every formulation of individual rights, churches are, however, in line with many proponents of human rights.

On the other hand the South African state and its people should bear in mind that its charter of human rights is only one of many around the world. It can be improved or changed (ironically enough the Christian church will tell you that) like any other effort of man (Smit 1984:90). The dignity of mankind as a general point of departure even outweighs the South African Bill of Rights.

\section{The church and the South African charter of human rights}

So far this article has focused on the state and human rights in the dominion or sphere of the state itself. We have also looked at the state in relation to other institutions of society, especially the church.

We now investigate the use of human rights by the church. Again it is a case of using it internally as well as in relation to other institutions in society. The church (normally) should promote human dignity as a consequence of obeying the Word of God and an integral part of brotherly love between the believers in church, but also in relation to other human beings. It should be a natural part of the church's approach of people, but also of its prophetic voice filled with an accepted biblically orientated justice, in society.

A biblical or true reformed church polity is by no means an end in itself. It serves to keep Christ and the Word at the head of the church. It should also act just. Plomp (1992:38-40) even calls it a serving justice.

The church is portrayed in principle as the body, temple, building and people of God. These descriptions point towards the unity and common identity of the church as a group of believers. Therefore, it can not only be interested in individual human rights. It should also support the right or freedom of association of these individuals who, by associating with certain institutions, broaden their individuality or personal ability with particulars of the unity and the calling of these associations. From a biblical point of view the core of the church as a body of Christian believers is that it is one body and, as such, a gift of God. That is one of the messages of terms like body, temple and building of God or Christ. This also implies that the character of this unity is and should be determined by God (Heyns 1970:44-45). A character formed in the uniting of 
the believers by the Holy Spirit as a gift of God and, as a right to freedom of religion, protected by law.

Again we talk about opportunities that become rights when God gives them to or established them amongst humans (Jonker 1984:53). Jonker's argument on opportunities and rights also echoes this broadening of individual rights or idea of collective human rights. This argument is in line with the confession that the authority of Christ as the Head, Saviour or Creator of the church is obeyed when the Word of God is obeyed (Jonker 1965:12). For a true Christian church this is even more fundamental than the idea of human rights!

On the issue of human rights the church should be looking for the right of the individual to freedom of speech, belief, choice in marriage, association, et cetera, but also for the right of institutions with certain identities manned by these individuals to act in search of their purpose or calling in society. These purposes can differentiate some institutions from others in a developed society.

It goes without saying that the church should promote justice in every aspect of its existence. That the church operating with the Word of God and aiming at the deepening and broadening of the Christian faith in people, at the same time should enhance the dignity and quality of the life of all human beings it comes across. Du Toit (1984) concludes his article on 'Teologie, kerk en menseregte' by connecting the idea of human rights to the process of growth in Christian holiness a holiness he integrates with every aspect of human life. For him it is a process of growth on the way to justice, human dignity and freedom. These concepts lay 'in die strukturele moontlikhede van sy menswees' [the structural competencies of humanity] as determined by God - something God, in his grace maintained after the fall of man in $\sin$ (Du Toit 1984:76). Moltmann (1984) adds that:

fundamental human rights ... mean those rights and duties, which belong essentially to what it means to be truly human, because without their being fully acknowledged and exercised human beings cannot fulfil their original destiny of having been created in the image of God. (p. 23 [author's emphasis])

If the church is practically 'of God', it operates with and on the basis of the Bible as the Word of God. At the same time it remains sensitive to the life-embracing call of man on earth. That is to be people of God in every aspect of life. The fulfilment of this calling goes hand in hand with the Godgiven restoration of justice, the dignity and the freedom of man after the fall in sin.

Internally the church gives effect to this understanding of human rights by the following examples.

In cases of discipline it operates with the rules of natural justice. This has been debated and supported in various publications (Coertzen 2003:210ff.; Du Plooy 2007:18ff.; Sadler 1979:51, 185-191). The rest of the church' work can also not be done without justice or respect for human dignity.
It is impossible to preach, to do pastoral care or to organise the youth or women without knowing and respecting their attitude and style in church. It is not good communication to bring members of the church a message, which misses a true or just understanding of their own situation, or makes unproved and unjustified allegations or statements. From a reformed perspective the church believe in the general priesthood of all believers (De Jong 1987:161). This implies an ear and an understanding for the dignity, merit, responsibility and view of every believer. Translated into terms of church governance it means the participation and equality of all members of assemblies in the actions at stake. It also supports the reformed principle of the equality of all offices, congregations and believers (Strauss 2010:8). For the church, as a body of believers to arrive together at the Godgiven purpose of the church, means the understanding, acceptance and support of it by every member. What is more, this implies the working together and respect for every member's dignity and ability.

Externally the insight of the church in the value and application of human rights should be two folded: In the first instance the church should have a clear understanding of its own right to freedom of and in religion (Nederduits Gereformeerde Kerk [NGK] 2011b:1). The church should also have an insight in a biblical approach of human rights and, together with its right to freedom of religion, promote it in society (Koffeman 2009:329). It should be part of its prophetic agenda.

In the second place it means that the church should be a champion for the justice and restored dignity of all people in its commentary on issues of society and its help for people in need. This dignity and justice form a framework within which people can be Christians in every aspect of life. The church should not only act to benefit its members, but also to serve potential members or all other people it encounters.

With regard to the Moderamen of the General Synod of the DRC, it spoke out publicly in recent years on issues in which justice and the rights of people played a dominant role. The report of the Moderamen to the General Synod of 2011 includes declarations, talks and physical aid to people involved in the problems of Zimbabwe. It makes contact with the leaders of political parties in South Africa, the government, the South African Police, the proposed charter of religious rights in South Africa and trade unions (NGK 2011a:207-209).

These DRC messages to the people involved, were sometimes given together with other churches and ecumenical bodies like the South African Council of Churches (NGK 2011a:207).

\section{Conclusion}

There is a lot of common ground between church and state in South African on human rights. It forms a common point of departure for promoting the idea of human rights in the country and even in Southern Africa. In seriously 
applying these rights, also in their contact and handling of one another, church and state form an impressive alliance for the establishment of human dignity in the everyday life in South Africa. The alliance may help the society to accept this dignity as a common custom or way of doing.

\section{Acknowledgements \\ Competing interests}

The author declares that he has no financial or personal relationship(s) that may have inappropriately influenced him in writing this article.

\section{References}

Coertzen, P., 1998, Church and order, Peeters, Leuven.

Coertzen, P., 2003, 'Regsbeskerming in die kerk', in R. Torfs, K. Martens \& L.J. Koffeman (eds.), Recht op recht in de kerk, pp. 199-258, Peeters, Leuven.

Constitutional Assembly, 1997, The constitution of the Republic of South Africa, Constitutional Assembly, Wynberg.

De Jong, O., 1987, Geschiedenis der kerk, Nijkerk, Callenbach.

Devenish, G.E., 1995, A commentary on the South African constitution, Butterworths, Johannesburg.

Dlamini, C.F.M., 1995, Human rights in Africa, Butterworths, Johannesburg.

Du Plooy, A le R., 2007, 'Beginsels vir regspraak in die kerk', Die Kerkblad, April, bl. 18-20.
Du Toit, D.A., 1984, 'Teologie, kerk en menseregte', in D.A. du Toit (red.), Menseregte, Tafelberg, Kaapstad.

Heyns, J.A., 1970, Die nuwe mens onderweg, Tafelberg, Kaapstad.

Jonker, W.D., 1965, Om die regering van Christus in sy kerk, Unisa, Pretoria.

Jonker, W.D., 1984, 'Christelike geloof en menseregte', in D.A. du Toit (red.), Menseregte, Tafelberg, Kaapstad.

Kleyn, D. \& Viljoen, F., 1998, Beginnersgids vir regstudente, 2e uitgawe, Juta, Kenwyn. Koffeman, L.J., 2009, Het goed recht van de kerk, Kok, Kampen.

Moltmann, J., 1984, On human dignity, SCM Press, London.

NGK, 2011a, Agenda van die 24e Algemene Sinode, Sn:sa.

NGK, 2011b, Die Kerkorde, Sn:sa.

Plomp, J., 1992, 'Kerk en recht', in W. van 't Spijker \& L.C. van Drimmelen (eds.), Inleiding tot de studie van het kerkrecht, pp. 32-42, Kok, Kampen.

Rautenbach, I.M. \& Malherbe, E.F.J., 1998, What does the constitution say?, Van Schaik, Pretoria.

Sadler, T.H.N., 1979, Die kerklike tughandeling, NG Kerkboekhandel, Pretoria.

Smit, C.J., 1984, God se orde vir sy kerk - 'n beskouing oor kerkorde, NG Kerkboekhandel, Pretoria.

Strauss, P.J., 2007, 'Die regsposisie van kerke in 'n verenigingsproses. Die NG Kerk teen die agtergrond van ontwikkelinge in België', NGTT 48(1 \& 2), 202-212. http:// dx.doi.org/10.17570/ngtt.2007.v48n1.a17

Strauss, P.J., 2010, Kerk en orde vandag, Sun Media, Bloemfontein.

Strauss, P.J., 2013, 'Church polity in a changing South Africa. A study of two Reformed churches', Studia Historiae Ecclesiasticae 34(1), 129-136.

Torfs, R., 2003, 'Rectsbescherming in de kerk. Nabeschouwingen', in R. Torfs (ed.), Recht op recht in de kerk, pp. 259-284, Peeters, Leuven.

Van der Vyver, J.D., 2011, 'Soewereiniteit van kerklike organisasies - die geval van die Moreletaparkse gemeente van die NG Kerk', Dejure 2, 1-17.

Visser, J., 1999, Die kerkorde in praktyk, EFJS-drukkers, Orkney. 